\title{
Effect of Holstein Friesian and Brown Swiss Breeds on Quality of Milk and Cheese
}

\author{
M. De Marchi, ${ }^{1}$ G. Bittante, R. Dal Zotto, C. Dalvit, and M. Cassandro \\ Department of Animal Science, University of Padova, Viale dell'Università 16, 35020 Legnaro, Padova, Italy
}

\begin{abstract}
In Italy, more than $75 \%$ of milk is used for cheese making. For this reason, milk composition and coagulation traits and cheese quality represent the most important tools for the economic development of the dairy sector. In particular, cheese quality varies in relation to cheese-making technology and breed of cow. The aim of this study was to investigate the effect of 3 types of milk, originating from Holstein-Friesian (HF), Brown Swiss (BS), and mixed of both breeds, on vat milk characteristics, cheese yield, and quality in 3 different typical Italian cheese-making conditions (Casolet, Vezzena, and Grana Trentino). One hundred forty-four cows (66 $\mathrm{HF}$ and $78 \mathrm{BS}$ ) were involved, and a total of 24 vats of milk were evaluated. At maturity, 30, 21, and 16 wheels of Casolet, Vezzena, and Grana Trentino cheese were analyzed. Brown Swiss cows yielded 9\% less milk per day than HF cows, but milk showed greater contents of protein, casein, titratable acidity, and better rennet coagulation time and curd firmness than HF milk. The chemical composition and cholesterol content of the 3 types of cheese were similar between breeds, whereas the cheese made with BS milk showed greater contents of monounsaturated and polyunsaturated fatty acids. Cheese made with BS milk had greater $b^{*}$ (yellow component) than HF. Cheese yield, recorded at different ripening times, demonstrated that BS milk yielded more cheese than HF. Mixed milk showed values, on average, intermediate to $\mathrm{HF}$ and $\mathrm{BS}$ milk characteristics, and this trend was confirmed in cheese yield at different ripening times.
\end{abstract}

Key words: breed effect, cheese quality and yield, Holstein Friesian, Brown Swiss

\section{INTRODUCTION}

Cheese yield, nutritional characteristics, and sensorial properties are affected by several genetic, environmental, and technological factors (Coulon et al., 2004).

\footnotetext{
Received October 17, 2007.

Accepted May 19, 2008.

${ }^{1}$ Corresponding author: Massimo.demarchi@unipd.it
}

Breed is the main genetic aspect affecting milk quality characteristics and, consequently, cheese-making technology and quality of products. Differences in level of production and chemical and technological properties of milk have been widely demonstrated among dairy cattle breeds (Macheboeuf et al., 1993; Auldist et al., 2002, 2004; De Marchi et al., 2007). The HolsteinFriesian (HF) breed is well known for milk production, low protein content, and poor coagulation properties of milk (Macheboeuf et al., 1993; Auldist et al., 2002; Mistry et al., 2002; De Marchi et al., 2007). HolsteinFriesian is characterized by a low frequency of the K-casein (CSN3) B variant (Grosclaude, 1988) and low casein number (Macheboeuf et al., 1993; Verdier-Metz, 2000). The Jersey and Brown Swiss (BS) breeds are well known for a lower milk production level, but with greater fat and protein content and better coagulation properties of milk (Auldist et al., 2004; De Marchi et al., 2007).

The quality of milk used for cheese production is very important for many typical products, some of them protected by the European label protected denomination of origin and protected geographic indication, where the link between final product and milk origin is very strong. Milk origin is particularly important when there is the possibility to link a product to a breed, to a region, and to a production system. In Italy, more than $75 \%$ of milk is used for cheese making, mainly typical protected denomination of origin products, and composition and coagulation traits of milk and quality of cheese represent the most important tools for the economic development of the dairy sector (Dalvit et al., 2007).

Only few studies have investigated the effect of breed of cows on quality of cheese. Garel and Coulon (1990) reported only small differences in color of typical SaintNectaire cheese produced by $\mathrm{HF}$ and Montbéliarde milk, whereas Martin et al. (2000) did not find any difference in quality of cheese among Tarentaise, HF, and Montbèliarde cattle breeds. Verdier-Metz et al. (2000), in a study including HF, Montbèliarde, and Tarentaise cattle breeds, observed differences in milk coagulation properties (MCP), but not in the chemical and physical characteristics, of cheese. Auldist et al. (2004) found 
no difference in cheese composition between Friesian and Jersey breeds. In Italy, the relationship between breed of cow and quality of milk and cheese has been investigated since the 1970s (Mariani and Russo, 1976; Pecorari et al., 1987; Mariani et al., 2002; Malacarne et al., 2006; De Marchi et al., 2007). The aims of this study were as follows: (1) to investigate the effect of $\mathrm{HF}$ and BS breeds on vat milk characteristics, cheese yield, and quality of Italian Casolet (full-cream and soft cheese), Vezzena, and Grana Trentino (semiskimmed and hard cheeses) and (2) to investigate the use of mixed (M) milk (half of HF and half of BS milk) on cheese yield and quality.

\section{MATERIALS AND METHODS}

\section{Experimental Design}

Three trials were carried out from May 2003 to January 2005 in 3 different dairy cooperatives located in the Trento province of the Italian Alps, each one specialized in a typical cheese production. Table 1 shows the technological characteristics of the 3 different types of cheese. Casolet (trial 1) is a full-cream, soft cheese (short ripening) made with pasteurized milk, whereas Vezzena (trial 2) and Grana Trentino (trial 3) are semiskimmed, hard cheeses (long ripening) prepared with raw milk. Grana Trentino is a type of cheese very close to Parmigiano-Reggiano in term of restrictions on cow feeding (prohibition to use silage) and cheese-making technology (the use of lysozyme is not allowed) but produced only with milk from alpine farms. Table 2 shows the experimental design of the 3 trials. Among the associated farmers, 3 representative of the mountain Alpine dairy farms were selected per each dairy cooperative, choosing farms with both $\mathrm{HF}$ and BS cows (mainly of North American genetics) reared in the same way, without any separation or preferential treatment. Therefore, size, location, management practices, and feeding strategies were comparable among and within herds. Feeding was based on the use of meadow and dried alfalfa hay as main forage sources and concentrates based on ground corn and soybean meal given accordingly to milk production.

A total of $66 \mathrm{HF}$ and $78 \mathrm{BS}$ cows were selected according to age and day in milk to obtain the milk needed for the trials (Table 3). Three types of milk were used per each cheese-making technology: HF milk, BS milk, and $\mathrm{M}$ milk obtained by blending half milk from $\mathrm{HF}$ and half milk from BS.

\section{Laboratory Analyses and Cheese Yield}

Qualitative analyses of individual and vat milk samples and cheese samples were carried out. Individual milk samples were taken in the morning of the cheesemaking day. The vat milk samples were collected before each cheese making. Ripened cheese samples were collected at 2, 12, and 12 mo for Casolet, Vezzena, and Grana Trentino, respectively.

Fat, protein, casein, and lactose content; titratable acidity value (Soxhlet-Henkel acidity); SCC; bacterial count; and MCP were determined on individual milk samples. Also, protein genetic variants at $\alpha_{\mathrm{s} 1^{-}}$ casein (CSN1S1), B-casein (CSN2), and CSN3 and B-lactoglobulin (LGB) loci were determined by isoelectric focusing analysis (Russo et al., 1984) on individual milk samples. This technique did not permit the distinction of $\mathrm{A} 1$ and $\mathrm{A} 2$ genetic variants of $\mathrm{CSN} 2$, so $\mathrm{A}$ (A1 and A2) and B alleles were compared. Fat, protein, and lactose content; titratable acidity value (SoxhletHenkel acidity); SCC; bacterial count; and MCP were determined on vat milk samples. Dry matter, ash, protein, and lipid contents; cholesterol content; fatty acid composition; color components: brightness $\left(\mathbf{L}^{*}\right)$, red component $\left(\mathbf{a}^{*}\right)$, and yellow component $\left(\mathbf{b}^{*}\right)$; and hardness values were determined for cheese samples.

Analyses of composition and MCP traits were performed by the Concast Laboratory (Trento, Italy). Milk coagulation properties were analyzed without preservative within $3 \mathrm{~h}$ from collection, whereas other compositional analyses were carried out within $24 \mathrm{~h}$ from collection on milk samples with Azidiol preservative (Concast Laboratory). Chemical composition (fat, protein, casein, and lactose content) of milk was analyzed using Midinfrared instruments (IDF, 2000), titratable acidity was recorded as Soxhlet-Henkel degree ( $\left.{ }^{\circ} \mathrm{SH}\right)$ according to the method proposed by Anonymous (1963), SCC was obtained using a direct microscopic method according to standard methods proposed by the IDF (1995), and bacterial count was determined by Bactoscan 8000 according to standard methods proposed by the IDF (1991). Somatic cell and bacterial counts were transformed to SCS and log bacterial count (LBC) by base-2 logarithm and natural logarithm, respectively. Measurements of MCP were carried out by Formagraph (Foss Electric, Hillerød, Denmark), which allowed milk samples to coagulate for a maximum of 30 min (Annibaldi et al., 1977).

Analyses of chemical and physical traits of cheese samples were performed by the Laboratory of Department of Animal Science (Padova, Italy). Cheese samples were analyzed for moisture by vacuum oven at $100^{\circ} \mathrm{C}$ (method 926.08; AOAC, 2003), fat by the Mojonnier method (method 933.05; AOAC, 2003), ash using a muffle furnace at $550^{\circ} \mathrm{C}(\operatorname{method} 935.42 ; \mathrm{AOAC}, 2000)$, and total protein by macro-Kjeldahl (method 2001.14; AOAC, 2002). Cholesterol content was obtained according to Casiraghi et al. (1994) using a Perkin Elmer 
Table 1. Description of cheese-making technologies and characteristics of Casolet, Vezzena, and Grana Trentino cheeses

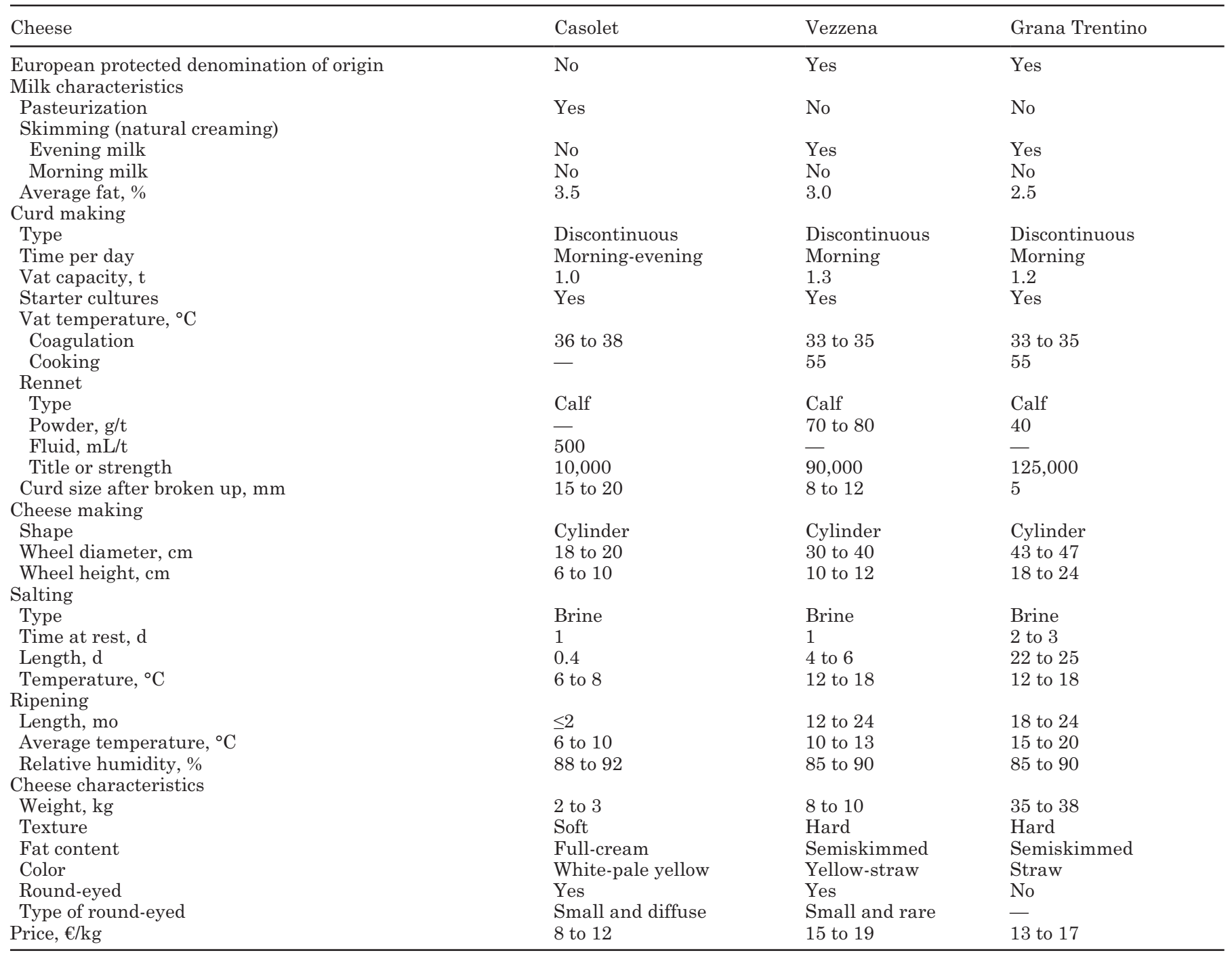

model UV LC 90 gas chromatograph (Perkin Elmer, Waltham, MA).

Color was determined with a colorimeter (Spectrophotometer CM-508, Minolta, Germany; illuminant: D65, observer: $10^{\circ}$ ) according to the method of CIELAB (1976). The color space model was chosen to numerically describe the color components $\left(\mathrm{L}^{*}, \mathrm{a}^{*}\right.$, and $\left.\mathrm{b}^{*}\right)$.

Cheese hardness was assessed using a WarnerBratzler shear force meter (Instron Ltd., High Wycombe, UK) on parallelepiped sample (1 cm height, 2 $\mathrm{cm}$ width, and $3 \mathrm{~cm}$ length). The crosshead speed was $2 \mathrm{~mm} / \mathrm{s}$, and the maximum peak force necessary to cut each parallelepiped transversally and completely was recorded.

The 30 wheels of Casolet were weighed at 1, 30, and $60 \mathrm{~d}$, whereas the 21 and 16 wheels of Vezzena and Grana Trentino cheeses, respectively, were weighed at
1, 30, 180, and $365 \mathrm{~d}$. Cheese yield (CY) was expressed as kilograms of cheese per one hundred kilograms of milk processed.

\section{Statistical Analyses}

Statistical models were fit with the GLM procedure of SAS Institute (1996). Lactation traits were analyzed as continuous traits according to the following linear model:

$$
\begin{gathered}
\mathrm{Y}_{\mathrm{ijkl}}=\mu+\text { breed }_{\mathrm{i}}+\operatorname{trial}_{\mathrm{j}}+\operatorname{herd}_{\mathrm{k}}\left(\operatorname{trial}_{\mathrm{j}}+\text { breed }_{\mathrm{i}}\right. \\
\times \operatorname{trial}_{\mathrm{j}}+\mathrm{e}_{\mathrm{ijkk}},
\end{gathered}
$$

where $\mathrm{Y}_{\mathrm{ijk} \mathrm{l}}=\mathrm{DIM}$, lactation number, milk yield; $\mu=$ overall mean; breed $_{i}=$ fixed effect of breed $\mathrm{i}(\mathrm{i}=\mathrm{HF}$, 
Table 2. Description of the experimental design ${ }^{1}$

\begin{tabular}{|c|c|c|c|}
\hline Item & \multicolumn{3}{|c|}{ Trial-type of cheese } \\
\hline Cooperative dairy & Cercen & Lavarone & Romeno-Cavareno \\
\hline Herds, n & 3 & 3 & 3 \\
\hline Cows used, $\mathrm{n}$ & $21 \mathrm{HF}$ and $22 \mathrm{BS}$ & $19 \mathrm{HF}$ and $22 \mathrm{BS}$ & $26 \mathrm{HF}$ and $34 \mathrm{BS}$ \\
\hline Milking type used & Morning & Morning and evening & Morning and evening \\
\hline Ripening, mo & 2 & 12 & 12 \\
\hline Wheels sampled, n & $10 \mathrm{HF}, 10 \mathrm{BS}$, and $10 \mathrm{M}$ & $7 \mathrm{HF}, 7 \mathrm{BS}$, and $7 \mathrm{M}$ & $4 \mathrm{HF}, 4 \mathrm{BS}$, and $8 \mathrm{M}$ \\
\hline
\end{tabular}

${ }^{1} \mathrm{HF}=$ Holstein-Friesian milk; BS = Brown Swiss milk; $\mathrm{M}=$ mixed milk.

$\mathrm{BS}) ;$ trial $_{\mathrm{j}}=$ fixed effect of the $\mathrm{jth}$ trial $(\mathrm{j}=$ Casolet, Vezzena, Grana Trentino); herd $\mathrm{d}_{\mathrm{k}}\left(\right.$ trial $\left._{\mathrm{j}}\right)=$ fixed effect of the kth herd $(\mathrm{k}=1 \ldots 3)$ within $\mathrm{jth}$ trial $(\mathrm{j}=$ Casolet, Vezzena, Grana Trentino); breed $_{i} \times$ trial $_{j}=$ first order interaction; $\mathrm{e}_{\mathrm{ijkl}}=$ residual random error term $\sim \mathrm{N}\left(0, \sigma_{e}^{2}\right)$. Because herds (nested) are different in different trials, the significance of trial effect was tested on the error line of the herd within trial. For each main effect, a multiple comparison of means was performed, using the Bonferroni test $(P<0.05)$.

For each protein genetic variant (i.e., CSN1S1, CSN2, CSN3, LGB), allele frequencies between breed were compared using the $\mathrm{X}^{2}$ test. Fisher's exact test was used when the expected count in $>25 \%$ of the cells was $<5$.

Individual milk composition and coagulation traits were analyzed as continuous traits according to the following linear model:

$$
\begin{aligned}
\mathrm{Y}_{\mathrm{ijklmn}}= & \mu+\operatorname{breed}_{\mathrm{i}}+\operatorname{trial}_{\mathrm{j}}+\operatorname{herd}_{\mathrm{k}}\left(\text { trial }_{\mathrm{j}}+\text { breed }_{\mathrm{i}}\right. \\
& \times \text { trial }_{\mathrm{j}}+\text { lact }_{\mathrm{l}}+\text { parity }_{\mathrm{m}}+\mathrm{e}_{\mathrm{ijklmn}},
\end{aligned}
$$

where $Y_{i j k l m n}=$ fat, protein, casein, and lactose content, titratable acidity value, SCS, LBC, and MCP traits; $\mu=$

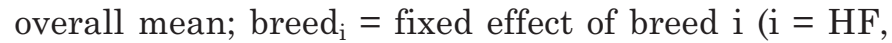
$\mathrm{BS}) ;$ trial $_{\mathrm{j}}=$ fixed effect of the $\mathrm{jth}$ trial $(\mathrm{j}=$ Casolet, Vezzena, Grana Trentino); herd $d_{k}(\text { trial })_{j}=$ fixed effect of the kth herd $(\mathrm{k}=1 . .3)$ within $\mathrm{jth}$ trial $(\mathrm{j}=$ Casolet, Vezzena, Grana Trentino); breed $_{i} \times$ trial $_{j}=$ first order interaction; lact $_{1}=$ fixed effect of the lth DIM $(\mathrm{l}=1 \ldots 3)$; parity $_{\mathrm{m}}$ $=$ fixed effect of the mth parity $(\mathrm{m}=1 \ldots 3) ; \mathrm{e}_{\mathrm{ijklmn}}=$ residual random error term $\sim \mathrm{N}\left(0, \sigma_{e}^{2}\right)$. The DIM and parity were categorized into 3 classes: $1:<100 \mathrm{~d} ; 2: 100$ to $200 \mathrm{~d} ; 3>200 \mathrm{~d}$ and $1=1$ parity; $2=2$ and 3 parities; 3 $\geq 3$ parities, for DIM and parity, respectively. For each main effect, a multiple comparison of means was performed, using the Bonferroni test $(P<0.05)$.
Vat milk composition and coagulation traits were analyzed as continuous traits according to the following linear model:

$$
\mathrm{Y}_{\mathrm{ijkl}}=\mu+\text { breed }_{\mathrm{i}}+\text { trial }_{\mathrm{j}}+\operatorname{repl}_{\mathrm{k}}+\mathrm{e}_{\mathrm{ijkl}},
$$

where $\mathrm{Y}_{\mathrm{ijkl}}=$ fat, protein, and lactose content, titratable acidity value, SCS, LBC, MCP traits, and CY; $\mu=$ overall mean; breed $_{i}=$ fixed effect of breed i $(i=H F, B S$, and

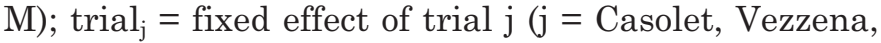
and Grana Trentino); repl $_{\mathrm{k}}=$ fixed effect of replicate $\mathrm{k}$ ( $\mathrm{k}=1$ : first, 2 : second); and $\mathrm{e}_{\mathrm{ijkl}}=$ residual random error term $\sim \mathrm{N}\left(0, \sigma_{e}^{2}\right)$.

Cheese chemical and physical traits of each trial were analyzed as continuous traits according to the following linear model:

$$
\mathrm{Y}_{\mathrm{ijk}}=\mu+\text { breed }_{\mathrm{i}}+\operatorname{repl}_{\mathrm{j}}+\mathrm{e}_{\mathrm{ijk}},
$$

where $\mathrm{Y}_{\mathrm{ijk}}=$ dry matter, ash, protein, and lipid content; cholesterol content; individual and grouped fatty acids; color components; and hardness values; $\mu=$ overall mean; breed $_{\mathrm{i}}=$ fixed effect of breed i $(\mathrm{i}=\mathrm{HF}, \mathrm{BS}$, and $\mathrm{M}) ;$ repl $_{\mathrm{j}}=$ fixed effect of replicate $\mathrm{j}(\mathrm{j}=1$ : first, 2 : second); and $\mathrm{e}_{\mathrm{ijk}}=$ residual random error term $\sim \mathrm{N}\left(0, \sigma_{e}^{2}\right)$. The level of significance was set to $P<0.05, P<0.01$, and $P<0.001$.

\section{RESULTS AND DISCUSSION}

\section{Characteristics of Individual Milk}

Lactation and milk composition traits of the 3 trials were comparable (Table 3) with the only exception of protein, casein content, titratable acidity, and LBC. The protein and casein content were greater for trial 2 (3.54 and $2.67 \%$, respectively) than for trial 1 (3.31 and $2.50 \%$, respectively) and trial 3 (3.18 and $2.44 \%$, re- 
Table 3. Least squares means of breed and trial effects and root mean square error (RMSE) of lactation traits, individual milk composition, and coagulation traits

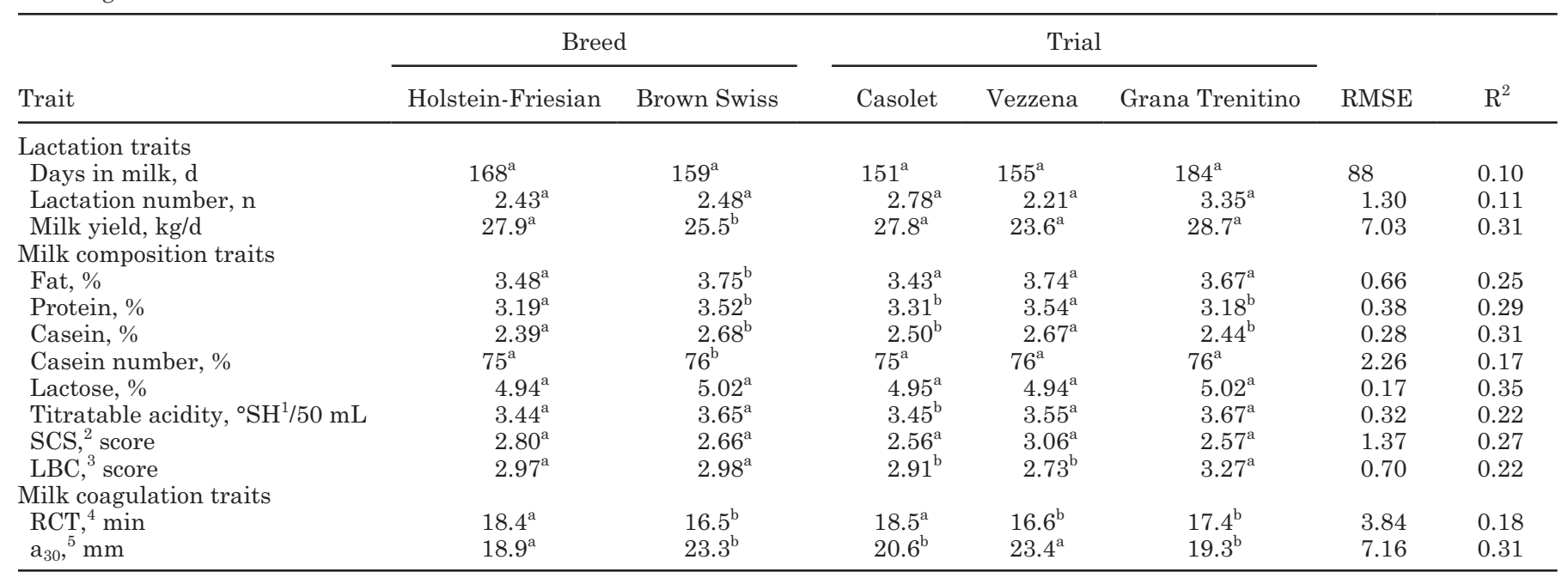

${ }^{\mathrm{a}, \mathrm{b}}$ Means with different letters differ significantly $(P<0.05)$ according to the Bonferroni test.

${ }^{1}{ }^{\circ} \mathrm{SH}=$ Soxhlet-Henkel degree.

${ }^{2} \mathrm{SCS}=\log _{2}$ of SCC.

${ }^{3} \mathrm{LBC}=$ natural log of bacterial count.

${ }^{4} \mathrm{RCT}=$ rennet coagulation time.

${ }^{5} \mathrm{a}_{30}=$ curd firmness.

spectively). Also, the titratable acidity was greater for trials 2 and 3 (3.55 and $3.67{ }^{\circ} \mathrm{SH} / 50 \mathrm{~mL}$, respectively) than for trial $1\left(3.45^{\circ} \mathrm{SH} / 50 \mathrm{~mL}\right)$. The $\mathrm{LBC}$ was greater in trial 3 (3.27) than for trial 1 and 2 (2.91 and 2.73, respectively). The effect of herd within trial was significant for milk yield, fat, casein number, lactose, SCS, $\mathrm{LBC}$, and $\mathrm{a}_{30}$ and not significant for protein, casein, titratable acidity, and rennet coagulation time (RCT; data not shown). Cows of the 2 breeds were balanced for lactation number and DIM, whereas, as expected, milk yield was greater (9\%) for HF than BS cows.

Fisher exact and $x^{2}$ tests revealed significant differences in allele frequencies between breeds for CSN1S1 $(P<0.01)$, CSN2 $(P<0.01)$, and CSN3 $(P<0.001)$, whereas the genetic variants of LGB were not. The results confirmed the superiority of BS cows for all the casein variants considered more favorable for cheesemaking ability (Mariani et al., 1976; Schaar, 1984, 1985). Relationship between casein fractions (CSN1S1, CSN2, and CSN3) as well as whey protein (LGB), composition of milk, and its technological properties have been widely studied (Ng-Kwai-Hang et al., 1984, 1986; Pagnacco, 1986; Caroli, 1987; Aleandri et al., 1990; Celik, 2003). Brown Swiss milk is known for greater frequency of CSN3 BB and LGB BB genotypes with respect to $\mathrm{HF}$, and these casein fractions are known to be associated with increased protein (Ng-Kwai-Hang et al., 1984, 1986; Aleandri et al., 1990) and lipid contents (Aleandri et al., 1990; Celik, 2003).
Brown Swiss cows involved in the 3 trials confirmed their significant superiority for all milk quality traits. Fat, protein, and casein contents of $\mathrm{HF}$ and BS milk were consistent with those reported by AIA (2006) and Mariani et al. (1997, 2002) in Italian conditions. Values of titratable acidity were greater for BS with respect to HF, as reported by Mariani et al. (1997, 2002). Brown Swiss had superior coagulation traits, including faster RCT (16.3 vs. $18.1 \mathrm{~min})$ and greater curd firmness $\left(\mathrm{a}_{30}\right.$ 23.9 vs. $19.4 \mathrm{~mm}$ ) than HF (Table 3), which is in agreement with Mariani et al. (1997, 2002) and De Marchi et al. (2007).

Milk coagulation traits are strongly correlated to milk acidity parameters such as $\mathrm{pH}$ and titratable acidity (Mariani et al., 1981; Remeuf and Hurtaud, 1991). Larger titratable acidity values of BS in this study were associated with better coagulation properties.

\section{Characteristics of Vat Milk}

The analyses performed on vat milk samples tended to confirm the data of individual samples, although the level of significance is much lower due to the lower number of taken samples (1 per vat; Tables 4, 5, and 6). Only protein content was greater (BS vats vs. HF) in all 3 trials. Malacarne et al. (2006) found in vat milk for Parmigiano-Reggiano cheese that the protein percentage of BS was significantly greater than HF. 
Mixed breed vat milk did not show any consistent difference with respect to the average between $\mathrm{HF}$ and BS values, with the exception of protein and lactose percentage of trial 2 (Vezzena cheese). Concerning the coagulation properties, the RCT values were smaller and $\mathrm{a}_{30}$ larger for BS than for HF, but these differences did not reach the statistical significance. Comparing the results of the 3 trials, while RCT values of M breed milk were erratic, $a_{30}$ values were very close to that of the BS milk, or even superior, and significantly greater than the intermediate expected value, like in trial 2
(Table 5). These results indicate a possible nonadditive positive effect of BS milk when mixed with HF milk, in terms of $\mathrm{a}_{30}$. Further studies on this topic should be performed to verify this hypothesis, because no similar results can be found in literature.

\section{Characteristics of Cheese}

The average chemical composition of the 3 cheeses produced (Tables 4, 5, and 6) reflects the different technologies used. It also agrees with the data obtained

Table 4. Trial 1 (Casolet cheese): least squares means (LSM), contrasts, and root mean square error (RMSE) of vat milk and cheese traits

\begin{tabular}{|c|c|c|c|c|c|c|c|}
\hline \multirow[b]{2}{*}{ Traits } & \multicolumn{3}{|c|}{ LSM } & \multicolumn{2}{|c|}{ Contrast } & \multirow[b]{2}{*}{ RMSE } & \multirow[b]{2}{*}{$\mathrm{R}^{2}$} \\
\hline & $\mathrm{HF}$ & $\mathrm{BS}$ & M & Breed & Mixed $^{1}$ & & \\
\hline \multicolumn{8}{|l|}{ Vat milk chemical traits } \\
\hline Fat, \% & 3.23 & 3.56 & 3.36 & NS & NS & 0.19 & 0.86 \\
\hline Protein, \% & 3.16 & 3.42 & 3.28 & $* * *$ & NS & 0.03 & 0.98 \\
\hline Lactose, \% & 4.91 & 4.94 & 4.95 & NS & NS & 0.03 & 0.90 \\
\hline Titratable acidity, ${ }^{\circ} \mathrm{SH}^{2} / 50 \mathrm{~mL}$ & 3.15 & 3.45 & 3.45 & NS & NS & 0.16 & 0.65 \\
\hline SCS, ${ }^{3}$ score & 4.21 & 3.19 & 3.64 & $* *$ & NS & 0.28 & 0.73 \\
\hline LBC, ${ }^{4}$ score & 3.94 & 3.96 & 4.23 & NS & NS & 0.76 & 0.75 \\
\hline \multicolumn{8}{|l|}{ Vat milk coagulation traits } \\
\hline $\mathrm{RCT}^{5}{ }^{\mathrm{m}} \min$ & 16.9 & 16.0 & 17.6 & NS & NS & 2.2 & 0.59 \\
\hline $\mathrm{a}_{30},{ }^{6} \mathrm{~mm}$ & 18.0 & 25.6 & 24.0 & NS & NS & 4.51 & 0.59 \\
\hline \multicolumn{8}{|l|}{ Cheese chemical traits } \\
\hline Dry matter, \% & 58.8 & 58.1 & 58.0 & NS & NS & 1.13 & 0.50 \\
\hline Ash, \% & 4.38 & 4.32 & 4.12 & NS & $* *$ & 0.16 & 0.56 \\
\hline Protein, \% & 23.58 & 23.35 & 23.67 & NS & NS & 0.62 & 0.30 \\
\hline Lipid, \% & 27.47 & 27.33 & 26.01 & NS & $* *$ & 1.14 & 0.55 \\
\hline Cholesterol, mg/100 g & 166 & 163 & 166 & NS & NS & 11 & 0.13 \\
\hline \multicolumn{8}{|c|}{ Cheese fatty acid composition (\% total fat) } \\
\hline $\mathrm{C} 4: 0$ & 3.42 & 3.20 & 3.30 & $* * *$ & NS & 0.08 & 0.61 \\
\hline $\mathrm{C} 6: 0$ & 3.05 & 2.96 & 3.00 & $* * *$ & NS & 0.04 & 0.82 \\
\hline $\mathrm{C} 8: 0$ & 1.97 & 1.90 & 1.94 & $* * *$ & NS & 0.03 & 0.82 \\
\hline C10:0 & 4.44 & 4.56 & 4.39 & $* * *$ & NS & 0.05 & 0.87 \\
\hline C12:0 & 4.76 & 4.63 & 4.67 & $* * *$ & NS & 0.05 & 0.86 \\
\hline C14:0 & 13.89 & 13.09 & 13.49 & $* * *$ & NS & 0.08 & 0.97 \\
\hline C16:0 & 29.20 & 27.88 & 28.48 & $* * *$ & NS & 0.14 & 0.96 \\
\hline C17:0 & 0.62 & 0.66 & 0.65 & $* * *$ & NS & 0.02 & 0.71 \\
\hline C18:0 & 7.64 & 8.86 & 8.32 & $* * *$ & $* *$ & 0.07 & 0.99 \\
\hline C16:1 n-7 & 1.53 & 1.59 & 1.58 & $* * *$ & $*$ & 0.03 & 0.85 \\
\hline C18:1 trans -7 & 1.34 & 1.50 & 1.44 & $* * *$ & NS & 0.04 & 0.86 \\
\hline C18:1 cis-9 & 16.40 & 17.03 & 16.47 & $* * *$ & $* * *$ & 0.09 & 0.96 \\
\hline C18:2 trans-1 & 0.46 & 0.42 & 0.49 & NS & NS & 0.08 & 0.43 \\
\hline C18:3 n-3 & 0.47 & 0.55 & 0.52 & $* * *$ & $* *$ & 0.01 & 0.96 \\
\hline $\mathrm{CLA}^{7}$ & 0.54 & 0.50 & 0.50 & $* * *$ & $*$ & 0.02 & 0.68 \\
\hline Saturated fatty acids & 72.29 & 70.89 & 71.64 & $* * *$ & NS & 0.32 & 0.89 \\
\hline Monounsaturated fatty acids & 23.31 & 24.25 & 23.68 & $* * *$ & NS & 0.13 & 0.96 \\
\hline Polyunsaturated fatty acids & 4.17 & 4.60 & 4.44 & $* * *$ & NS & 0.14 & 0.74 \\
\hline \multicolumn{8}{|l|}{ Cheese physical traits } \\
\hline $\mathrm{L}^{*}$ & 84.1 & 81.5 & 82.2 & $* * *$ & NS & 1.4 & 0.52 \\
\hline$a^{*}$ & -0.70 & -0.43 & -0.63 & $* * *$ & NS & 0.10 & 0.63 \\
\hline $\mathrm{b}^{*}$ & 9.37 & 10.69 & 9.71 & $* * *$ & NS & 0.42 & 0.71 \\
\hline Hardness, N & 6.02 & 6.56 & 6.18 & NS & NS & 1.01 & 0.77 \\
\hline
\end{tabular}

${ }^{1}$ Contrast between mixed (M) and the average of Holstein-Friesian (HF) and Brown Swiss (BS).

${ }^{2 \circ} \mathrm{SH}=$ Soxhlet-Henkel degree.

${ }^{3} \mathrm{SCS}=\log$ of SCC.

${ }^{4} \mathrm{LBC}=\log$ of bacterial count.

${ }^{5} \mathrm{RCT}=$ rennet coagulation time.

${ }^{6} \mathrm{a}_{30}=$ curd firmness.

${ }^{7} \mathrm{CLA}=$ conjugated linoleic acid.

${ }^{*} P<0.05 ;{ }^{* *} P<0.01 ; * * * P<0.001$. 
Table 5. Trial 2 (Vezzena cheese): least squares means (LSM), contrasts, and root mean square error (RMSE) of vat milk and cheese traits

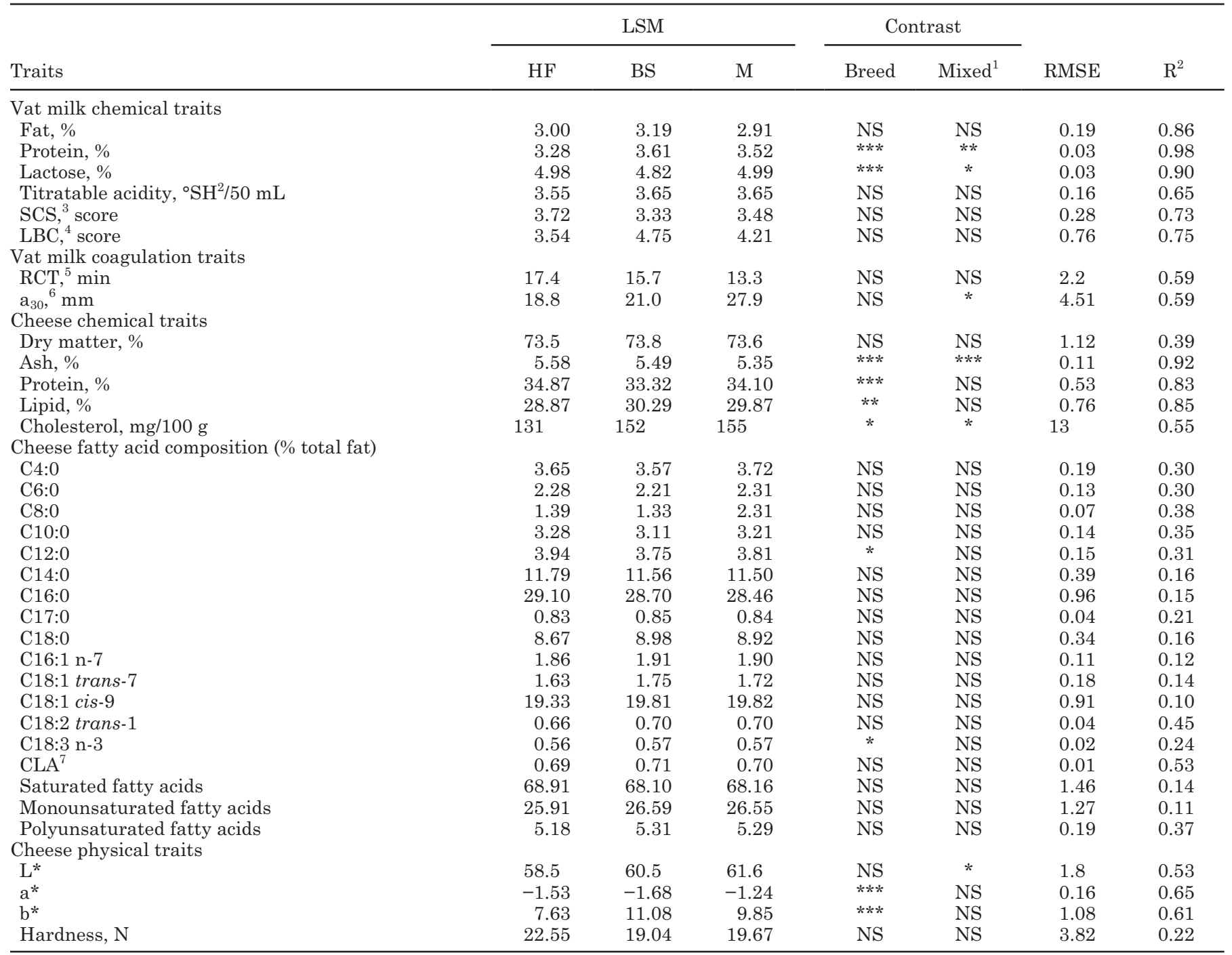

${ }^{1}$ Contrast between mixed (M) and the average of Holstein-Friesian (HF) and Brown Swiss (BS).

${ }^{2 \circ} \mathrm{SH}=$ Soxhlet-Henkel degree.

${ }^{3} \mathrm{SCS}=\log$ of SCC.

${ }^{4} \mathrm{LBC}=\log$ of bacterial count.

${ }^{5} \mathrm{RCT}=$ rennet coagulation time.

${ }^{6} \mathrm{a}_{30}=$ curd firmness.

${ }^{7} \mathrm{CLA}=$ conjugated linoleic acid.

${ }^{*} P<0.05 ;{ }^{* *} P<0.01 ; * * * P<0.001$.

from quality assessment procedures carried out by the 3 dairy factories.

Protein and fat content were similar for cheese made with HF and BS milk for Casolet and Grana Trentino, whereas for Vezzena, the protein content was lower and fat content was greater for cheese made with BS milk. Cholesterol content was greater in Casolet than in Vezzena and Grana Trentino, whereas there were no consistent differences between breeds. These findings are not in accordance with those found by Park (1999) and by Kinik et al. (2005) in their studies regarding different types of goat cheese. They found that hard cheeses, with high dry matter content, are usually richer in cholesterol. Cholesterol values of Vezzena and Grana Trentino ranged between 131 and $155 \mathrm{mg} / 100$ $\mathrm{g}$ and are consistent with those reported for Graviera, a hard variety of cheese from Crete (Andrikopoulos et al., 2003). Cheese made with $\mathrm{M}$ milk was similar in composition from purebred milk except for significant differences in ash and lipid contents. 
Table 6. Trial 3 (Grana Trentino cheese): least squares means (LSM), contrasts, and root mean square error (RMSE) of vat milk and cheese traits

\begin{tabular}{|c|c|c|c|c|c|c|c|}
\hline Traits & \multicolumn{3}{|c|}{ LSM } & \multicolumn{2}{|c|}{ Contrast } & RMSE & $\mathrm{R}^{2}$ \\
\hline \multicolumn{8}{|l|}{ Vat milk chemical traits } \\
\hline Protein, \% & 3.12 & 3.36 & 3.24 & $* * *$ & NS & 0.03 & 0.98 \\
\hline Lactose, $\%$ & 5.02 & 5.08 & 5.05 & NS & NS & 0.03 & 0.90 \\
\hline Titratable acidity, ${ }^{\circ} \mathrm{SH}^{2} / 50 \mathrm{~mL}$ & 3.35 & 3.60 & 3.45 & NS & NS & 0.16 & 0.65 \\
\hline \multicolumn{8}{|l|}{ Vat milk coagulation traits } \\
\hline $\mathrm{RCT}^{5}{ }^{\mathrm{min}}$ & 19.1 & 16.7 & 20.1 & NS & NS & 2.2 & 0.59 \\
\hline $\mathrm{a}_{30},{ }^{6} \mathrm{~mm}$ & 14.9 & 20.2 & 19.5 & NS & NS & 4.51 & 0.59 \\
\hline \multicolumn{8}{|l|}{ Cheese chemical traits } \\
\hline Dry matter, \% & 67.7 & 67.8 & 68.7 & NS & $* * *$ & 0.55 & 0.62 \\
\hline Ash, \% & 4.45 & 4.46 & 4.53 & NS & NS & 0.14 & 0.26 \\
\hline Protein, \% & 32.10 & 31.85 & 32.07 & NS & NS & 0.39 & 0.35 \\
\hline $\mathrm{C} 8: 0$ & 1.39 & 1.28 & 1.34 & $* *$ & NS & 0.04 & 0.73 \\
\hline $\mathrm{C} 10: 0$ & 2.95 & 2.73 & 2.88 & $* * *$ & NS & 0.05 & 0.79 \\
\hline C12:0 & 3.25 & 3.03 & 3.14 & $* *$ & NS & 0.08 & 0.72 \\
\hline $\mathrm{C} 14: 0$ & 10.93 & 9.91 & 10.52 & $* * *$ & NS & 0.13 & 0.93 \\
\hline C16:0 & 27.29 & 25.56 & 26.38 & $* * *$ & NS & 0.31 & 0.91 \\
\hline $\mathrm{C} 17: 0$ & 0.66 & 0.69 & 0.67 & * & NS & 0.01 & 0.58 \\
\hline $\mathrm{C} 18: 0$ & 10.79 & 12.27 & 11.58 & $* * *$ & NS & 0.12 & 0.98 \\
\hline C16:1 n-7 & 1.49 & 1.67 & 1.58 & $* * *$ & NS & 0.03 & 0.88 \\
\hline C18:1 trans -7 & 1.91 & 1.87 & 1.87 & NS & NS & 0.04 & 0.58 \\
\hline C18:1 cis-9 & 19.57 & 21.84 & 20.49 & $* * *$ & NS & 0.26 & 0.94 \\
\hline $\mathrm{C} 18: 2$ trans-1 & 0.64 & 0.61 & 0.65 & NS & NS & 0.14 & 0.27 \\
\hline C18:3 n-3 & 0.62 & 0.67 & 0.63 & $* *$ & NS & 0.02 & 0.69 \\
\hline CLA $^{7}$ & 0.77 & 0.66 & 0.69 & $* * *$ & NS & 0.03 & 0.79 \\
\hline Saturated fatty acids & 67.21 & 64.90 & 66.32 & $* * *$ & NS & 0.47 & 0.84 \\
\hline
\end{tabular}

${ }^{1}$ Contrast between mixed (M) and the average of Holstein-Friesian (HF) and Brown Swiss (BS).

${ }^{2} \circ \mathrm{SH}=$ Soxhlet-Henkel degree.

${ }^{3} \mathrm{SCS}=\log$ of SCC.

${ }^{4} \mathrm{LBC}=\log$ of bacterial count.

${ }^{5} \mathrm{RCT}=$ rennet coagulation time.

${ }^{6} \mathrm{a}_{30}=$ curd firmness.

${ }^{7} \mathrm{CLA}=$ conjugated linoleic acid.

${ }^{*} P<0.05 ;{ }^{* *} P<0.01 ;{ }^{* * *} P<0.001$.

Palmitic acid (C16:0) was the main fatty acid in all varieties of cheese, followed by $\mathrm{C} 18: 1$ cis-9 and $\mathrm{C} 14: 0$ (Tables 4, 5, and 6). This finding is consistent with that reported by Lucas et al. (2006) in French cheeses made with raw milk. Although cows of both breeds were reared together in the same herds and the rearing and feeding condition were the same, the effect of breed (HF vs. BS) was significant for almost all fatty acids present in the Casolet and Grana Trentino, but not in the Vez- zena cheese (Tables 4, 5, and 6), because the residual variability was much larger in this trial. Cheese from HF milk had a greater content of each saturated fatty acid (SFA) from C4:0 to C16:0 and total SFA, whereas the longer-chain SFA (C17:0 and C18:0) were greater in all cheese made with BS milk. Cheese made with BS milk had a larger content of almost every unsaturated fatty acid and of total mono- and polyunsaturated fatty acids. 


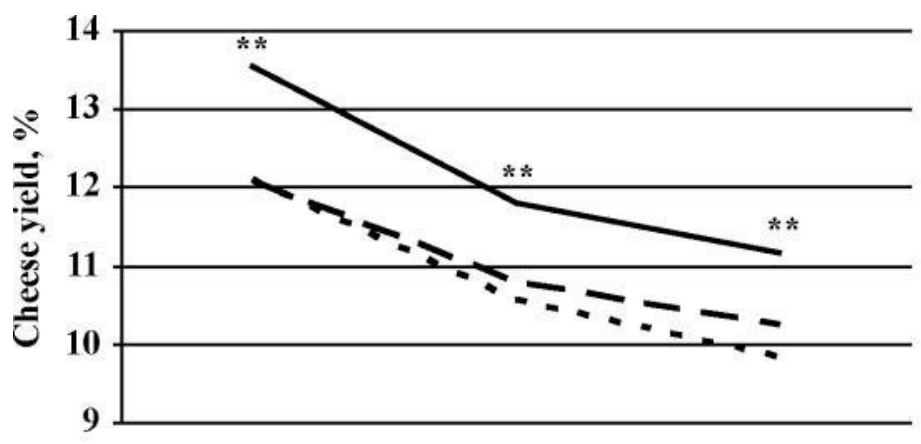

\section{Casolet cheese}
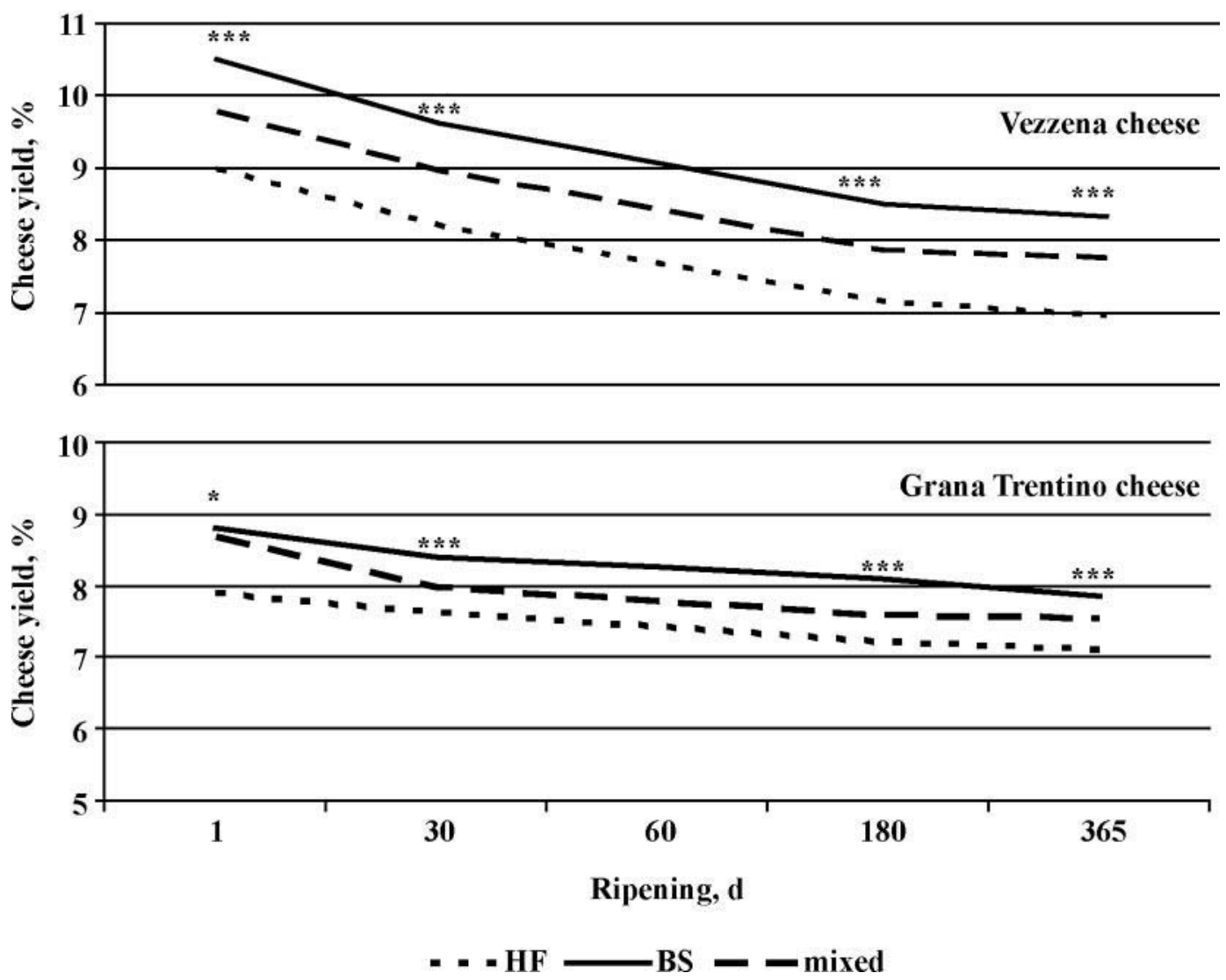

Figure 1. Least squares means of cheese yield (\%) for the Casolet, Vezzena, and Grana Trentino cheeses at different ripening times (1, 30, 60, 180, and 365 d). Contrast between Holstein-Friesian (HF) and Brown Swiss (BS): ${ }^{*} P<0.05 ;{ }^{* *} P<0.01 ;{ }^{* *} P<0.001$. Contrast between mixed and the average of $\mathrm{HF}$ and BS never significant.

Conjugated linoleic acid content was inconsistent among trials. In general, cheeses made with milk from BS cows had greater concentrations of fatty acids that are favored for human health. Cheese made with M milk tended to have intermediate fatty acid composition with respect to the cheese produced with the HF and BS milk. These differences are intrinsic of the 2 breeds, as reported by Carroll et al. (2006). Milk fat composition had an important effect on the cheese fat composition in relation to all fatty acids (Lucas et al., 2006), whereas the influence of cheese-making technol- ogy is relatively low (Gnädig et al., 2004; Lucas et al., 2006).

Cheese lightness gave inconsistent results, but cheese made with BS milk showed greater $b^{*}$ than HF, whereas it tended to present a more neutral a* (Tables 4,5 , and 6). Yellow cheese is preferred by consumers in the case of mountain products, because it is associated with the pasture-based system. No statistical differences were observed between breeds for the hardness values $(\mathrm{N})$ that were very different in the 3 cheeses. Hardness was greatest for Grana Trentino (31.1 to 
34.4) followed by Vezzena (19 to 22.6) and Casolet (6.0 to 6.6). Cheeses made with the $\mathrm{M}$ milk were not different from the average of $\mathrm{HF}$ and $\mathrm{BS}$ cheeses for the physical traits. According to our knowledge, no reference exits to compare these values.

\section{Cheese Yield}

Figure 1 shows the least squares means of CY (\%) for the 3 trials at different ripening times. According to the technologies employed, Casolet cheese showed the greatest CY percentages followed by Vezzena and Grana Trentino. At $24 \mathrm{~h}$ from production, CY (\%) from BS milk were markedly greater than HF milk, $+12 \%$, $+17 \%$, and $+12 \%$ for Casolet, Vezzena, and Grana Trentino cheeses, respectively. Cheese yield of Vezzena and Grana Trentino cheeses was recorded also at 180 and $365 \mathrm{~d}$ of ripening, and in all cases, BS showed greater CY (\%) than HF. It is evident that the increased CY (\%) of BS milk at $24 \mathrm{~h}$ is not totally explained by its greater protein-plus-fat content, because the superiority of $\mathrm{CY}$ is consistently greater than the superiority of protein-plus-fat content as in the case of Casolet $(+12 \%$ vs. $+9 \%)$, Vezzena ( $+17 \%$ vs. $+8 \%)$, and Grana Trentino $(+12 \%$ vs. $+9 \%)$. Brown Swiss milk gave an extra yield of 3 to $9 \%$ over the value expected on the basis of milk composition.

The CY (\%) of Grana Trentino at $1 \mathrm{yr}$ of ripening ranged from $7.1(\mathrm{HF})$ to 7.8 (BS), consistent with those reported by Malacarne et al. (2006) for ParmigianoReggiano, and the difference between the milk of the 2 breeds is related to the greater casein content of BS milk, as reported by Fossa et al. (1994) and Malacarne et al. (2006). Similar trends for HF and BS milk were reported by Mistry et al. (2002) in a Cheddar cheesemaking trial. Taking into account that the protein:fat ratio was very similar for $\mathrm{HF}$ and $\mathrm{BS}$ milk, the greater protein content and protein:fat ratio of $\mathrm{HF}$ cheese can reflect a lesser ability to retain fat from whey, thus explaining in part the greater CY (\%) of BS milk. As reported by Chapman (1981), CY (\%) of cheese made with $\mathrm{M}$ milk was intermediate between $\mathrm{HF}$ and $\mathrm{BS}$ milk. The better CY (\%) of BS milk has a marked economic relevance for the cheese industry, as reported by Malacarne et al. (2006).

\section{CONCLUSIONS}

This study confirmed the differences on milk quality and coagulation properties between HF and BS milk. Compared with HF, BS milk showed greater contents of protein, casein, titratable acidity, and superior values of RCT and $\mathrm{a}_{30}$. These differences were confirmed also in the vat milk of 3 typical cheeses of the Italian
Alps (Casolet, Vezzena, and Grana Trentino). Concerning the cheese characteristics, despite some differences among cheeses due to different technologies, no differences were observed between breeds in the chemical composition and in the cholesterol content, whereas BS cheeses had more MUFA and PUFA than HF. This result can be attributed only to genetic characteristics and not to feeding strategies of cows. These findings could be interesting, because some PUFA are known to play an important role in human health. Moreover, cheeses derived from BS milk had a preferred yellow color. Despite inferior milk yield $(-9 \%)$, BS cows yielded 3\% more Casolet, 9\% more Vezzena, and 3\% more Grana Trentino than did HF.

Brown Swiss cows yielded 15\% more cheese per kilogram of milk on average than HF cows. Per day, BS cows produced $9 \%$ less milk, the same protein-plus-fat yield and 5\% more cheese. The BS cows presumably also had a smaller daily energy requirement, because their lactose production was 7\% lower than HF cows. Mixed milk had observed values that were on average intermediate to $\mathrm{HF}$ and BS milk characteristics, and this trend was confirmed also in CY.

The results of this study suggest the need to consider coagulation traits for a more comprehensive payment system of milk used for cheese production. Moreover, the results underlined the importance of investigating the genetic basis of the breed differences in cheese production aptitude to evaluate the feasibility of withinbreed genetic improvement of these traits.

\section{ACKNOWLEDGMENTS}

We thank the Superbrown Consortium of Bolzano and Trento; Trento province; the dairy factories of Cercen (Terzolas, Trento, Italy), Lavarone (Lavarone, Trento, Italy), and Romeno Cavareno (Romeno, Trento, Italy); and Consorzio of Trentingrana - Concast (Trento, Italy). Moreover, we thank Alessio Cecchinato (University of Padova, Italy) and Andrea Summer University of Parma, Italy) for their suggestions.

\section{REFERENCES}

AIA. 2006. Bollettino dei controlli funzionali del latte. AIA, Rome, Italy.

Aleandri, R., L. G. Buttazzoni, J. C. Schneider, A. Caroli, and R. Davoli. 1990. The effect of milk protein polymorphisms on milk components and cheese producing ability. J. Dairy Sci. 73:241255.

Andrikopoulos, N. K., N. Kalogeropoulos, A. Zerva, U. Zerva, M. Hassapidou, and V. M. Kapoulas. 2003. Evaluation of cholesterol and other nutrient parameters of Greek cheese varieties. J. Food Compost. Anal. 16:155-168.

Annibaldi, S., G. Ferri, and R. Mora. 1977. Nuovi orientamenti nella valutazione tecnica del latte: Tipizzazione lattodinamografica. Sci. Tecn. Latt. Cas. 28:115-126. 
Anonymous, . 1963. Titratable acidity evaluation with the SoxhletHenkel (SH) method. Milchwissenschaft 18:520.

AOAC. 2000. Official Methods of Analysis. 17th ed. AOAC, Arlington, VA.

AOAC. 2002. Official Methods of Analysis. 17th ed. AOAC, Arlington, VA.

AOAC. 2003. Official Methods of Analysis. 17th ed. AOAC, Gaithersburg, MD.

Auldist, M. J., K. A. Johnston, N. J. White, W. P. Fitzsimons, and M. J. Boland. 2004. A comparison of the composition, coagulation characteristics and cheesemaking capacity of milk from Friesian and Jersey dairy cows. J. Dairy Res. 71:51-57.

Auldist, M., C. Mullins, B. O'Brien, B. T. O'Kennedy, and T. Guinee. 2002. Effect of cow breed on milk coagulation properties. Milchwissenschaft 5:140-143.

Carroll, S. M., E. J. DePeters, S. J. Taylor, M. Rosenberg, H. PerezMonti, and V. A. Capps. 2006. Milk composition of Holstein, Jersey, and Brown Swiss cows in response to increasing levels of dietary fat. Anim. Feed Sci. Technol. 131:451-473.

Casiraghi, E., M. Lucisano, C. Pompei, and C. Dellea. 1994. Cholesterol determination in butter by high performance chromatography. Milchwissenschaft 49:194-196.

Celik, S. 2003. B-Lactoglobulin genetic variants in Brown Swiss breed and its association with compositional properties and rennet clotting time of milk. Int. Dairy J. 13:727-731.

Chapman, H. R. 1981. Standardisation of milk for cheesemaking at research level. J. Soc. Dairy Technol. 34:147-152.

CIELAB. 1976. CIELAB Colour System. Commission International de l'Eclairage, Paris, France.

Coulon, J. B., A. Delacroix-Buchet, and B. Martin. 2004. Relationships between ruminant management and sensory characteristics of cheeses: A review. Lait 84:221-241.

Dalvit, C., M. De Marchi, and M. Cassandro. 2007. Genetic traceability of livestock products. A review. Meat Sci. 77:437-449.

De Marchi, M., R. Dal Zotto, M. Cassandro, and G. Bittante. 2007. Milk coagulation ability of five dairy cattle breeds. J. Dairy Sci. 90:3986-3992.

Fossa, E., M. Pecorari, S. Sandri, F. Tosi, and P. Mariani. 1994. The role of milk casein content in the Parmigiano-Reggiano cheese production: Chemical composition, rennet coagulation, rennet coagulation properties and dairy technological behaviour of milk. Sci. Tecn. Latt. Cas. 45:519-535.

Garel, J. P., and J. B. Coulon. 1990. Effet de l'alimentation et de la race des vaches sur les fabrications de fromage d'Auvergne de Saint-Nectaire, INRA . Prod. Anim. 3:127-136.

Gnädig, S., J. F. Chamba, E. Perreard, S. Chappaz, J. M. Chardigny, R. Rickert, H. Steinhart, and J. L. Sébédio. 2004. Influence of manufacturing conditions on the conjugated linoleic acid content and the isomer composition in ripened French Emmental cheese. J. Dairy Res. 71:367-371.

Grosclaude, F. 1988. Le polymorphisme génétique des principales lactoprotéines bovines. Relation avec la qualité, la composition et les aptitudes fromagères du lait. INRA . Prod. Anim. 1:5-17.

IDF. 1991. International IDF Standard 100B:1991 (Milk - Standard Plate Count.). IDF, Brussels, Belgium.

IDF. 1995. International IDF Standard 148A:1995 (Milk Enumeration of somatic cells.). IDF, Brussels, Belgium.

IDF. 2000. International IDF Standard 141C:2000 (Determination of milk fat, protein and lactose content. Guidance on the operation of mid-infrared instruments.). IDF, Brussels, Belgium.

Kinik, O., O. Gursoy, and K. Seckin. 2005. Cholesterol content and fatty acid composition of most consumed Turkish hard and soft cheeses. Czech. J. Food Sci. 23:166-172.

Lucas, A., E. Rock, J. F. Chamba, I. Verdier Metz, P. Brachet, and J. P. Coulon. 2006. Respective effects of milk composition and the cheese-making process on cheese compositional variability in components of nutritional interest. Lait 86:21-41.

Macheboeuf, D., J. B. Coulon, and P. D'Hour. 1993. Effect of breed, protein genetic variants and feeding on cows' milk coagulation properties. J. Dairy Res. 60:43-54.
Malacarne, M., A. Summer, E. Fossa, P. Formaggioni, P. Franceschi, M. Pecorari, and P. Mariani. 2006. Composition, coagulation properties and Parmigiano-Reggiano cheese yield of Italian Brown and Italian Friesian herd milks. J. Dairy Res. 73:171177.

Mariani, P., G. Losi, V. Russo, G. B. Castagnetti, L. Grazia, D. Morini, and E. Fossa. 1976. Cheesemaking trials with milk characterized by k-casein A and B variant in the production of the ParmigianoReggiano cheese. Sci. Tecn. Latt. Cas. 27:208-227.

Mariani, P., M. Pecorari, E. Fossa, and S. Fieni. 1981. Occurrence of bovine milk characterized by abnormal rennet-coagulability and relationships with cell content and titratable acidity. Sci. Tecn. Latt. Cas. 32:222-236.

Mariani, P., and V. Russo. 1976. Ricerche sul contenuto di calcio e fosforo nel latte delle razze Frisona, Bruna alpina, Reggiana, Modenese. Riv. Zoot. Vet. 4:23.

Mariani, P., P. Serventi, and E. Fossa. 1997. Contenuto di caseina, varianti genetiche ed attitudine tecnologico casearia del latte delle vacche di razza Bruna nella produzione del formaggio grana. Allegato a La Razza Bruna Italiana 2:8-14.

Mariani, P., A. Summer, P. Formaggioni, and M. Malacarne. 2002 La qualità casearia del latte di differenti razze bovine. Allegato a La Razza Bruna Italiana 1:7-13.

Martin, B., P. Pradel, and I. Verdier-Metz. 2000. Effet de la race (Holstein/Montbeliarde) sur les caractéristiques chimiques et sensorielles des fromages. Renc. Rech Rum 7:317.

Mistry, V. V., M. J. Brouk, K. M. Kasperson, and E. Martin. 2002 Cheddar cheese from milk of Holstein and Brown Swiss cows. Milchwissenschaft 57:19-23.

Ng-Kwai-Hang, K. F., J. F. Hayes, J. E. Moxley, and H. G. Monardes. 1984. Association of genetic variants of casein and milk serum proteins with milk, fat, and protein production by dairy cattle. J. Dairy Sci. 67:835-840.

Ng-Kwai-Hang, K. F., J. F. Hayes, J. E. Moxley, and H. G. Monardes, 1986. Relationships between milk protein polymorphisms and major milk constituents in Holstein-Friesian cows. J. Dairy Sci. 69:22-26.

Pagnacco, G., and A. Caroli. 1987. Effect of casein and B-lactoglobulin genotypes on renneting properties of milks. J. Dairy Res. $54: 479-485$.

Park, Y. W. 1999. Cholesterol contents of U.S. and imported goat milk cheeses as quantified by different cholorimetric methods. Small Rumin. Res. 32:77-82.

Pecorari, M., S. Sandri, and P. Mariani. 1987. Attitudine alla coagulazione die latti delle razze Frisona, Bruna, Reggiana e Modenese. Sci. Tecn. Latt. Cas. 38:376.

Remeuf, F., and C. Hurtaud. 1991. Relationship between physicochemical traits of milk and renneting property. Pages 1-7 in Qualité des Laits à la Production et Aptitude Fromagère (Milk Quality in Production and Cheesemaking Aptitude). M. Journet, A. Hoden, and G. Brule, ed. INRA, ENSAR, Rennes, France.

Russo, V., R. Davoli, P. Bosi, and P. Bruzzone. 1984. Varianti genetiche della beta-caseina a $\mathrm{pH}$ acido nelle razze bovine Bruna, Frisona Italiana, Modenese e Reggiana. Zoot. Nutr. Anim. $10: 47-53$.

SAS Institute. 1996. SAS User's Guide: Statistics. Version 7 ed. SAS Inst. Inc., Cary, NC.

Schaar, J. 1984. Effects of casein genetic variants and lactation number on the renneting properties of individual milks. J. Dairy Res. 51:397-406.

Schaar, J., B. Hansson, and H. E. Pettersson. 1985. Effects of genetic variants of $\mathrm{k}$-casein and B-lactoglobulin on cheesemaking. J. Dairy Res. 52:429-437.

Verdier-Metz, I., J. B. Coulon, P. Pradel, C. Viallon, H. Albouy, and J. L. Berdagué. 2000. Effect of the botanical composition of hay and casein genetic variants on the chemical and sensory characteristics of ripened Saint-Nectaire type cheese. Lait 80:361-370. 